KAWISTARA

VOLUME 4

No. 3, 22 Desember 2014

Halaman 225-330

\title{
MODEL PENGEMBANGAN EKOWISATA DALAM MENDUKUNG KEMANDIRIAN EKONOMI DAERAH STUDI KASUS PROVINSI DIY
}

\author{
Joko Tri Haryanto \\ Pusat Kebijakan Pembiayaan Perubahan Iklim dan Multilateral \\ Badan Kebijakan Fiskal, Kementerian Keuangan \\ Email: djohar78@gmail.com
}

\begin{abstract}
Along with the development and economic growth processing, the role of tourism nowadays is more essential, as new sectors that contibuting foreign exchange for the improvement of people's welfare. Indonesia is one country that has a many natural and cultural remarkable, also enjoy this benefit. However, tourism is often regarded as one of the largest damage contributor to the preservation of the environment and the community, particularly through the development of the infrastructure. Yogyakarta Province as one of the tourist destinations, also face the same problem, a shift in cultural values, social and environmental wisdom. Ecotourism then regarded as one of the policy alternatives that can be used as a solution to this problem. By using a qualitative approach, this study was conducted with the aim of formulating a model-based sustainable ecotourism cultural values, social, and environmental wisdom that will support the successful development of tourism in Yogyakarta. With the development of this policy model, expected to be a guideline for governments in developing national policies in the field of sustainable tourism in order to streng then the economic independence in the region.
\end{abstract}

Keywords: Eco-tourism, Tourism, Sustainable Tourism

\begin{abstract}
ABSTRAK
Seiring dengan pembangunan dan pertumbuhan ekonomi, peranan pariwisata dewasa ini semakin meningkat sebagai sektor baru penyumbang devisa yang cukup besar bagi peningkatan kesejahteraan masyarakat. Indonesia sebagai salah satu negara yang memiliki kekayaan alam dan budaya luar biasa, juga menikmati manfaat ini. Akan tetapi, pariwisata juga sering dianggap sebagai salah satu penyumbang kerusakan terbesar bagi kelestarian lingkungan dan masyarakat, khususnya melalui pembangunan infrastruktur pendukungnya. Provinsi Yogyakarta sebagai salah satu tujuan wisata, juga menghadapi permasalahan yang sama, ketika terjadi gejala pergeseran nilai-nilai budaya, sosial dan kearifan lingkungannya. Ekowisata, kemudian dipandang sebagai salah satu alternatif kebijakan yang dapat dijadikan solusi terhadap persoalan ini. Dengan menggunakan pendekatan kualitatif, kajian ini dilakukan dengan tujuan merumuskan model ekowisata berkelanjutan berbasis nilai-nilai budaya, sosial dan kearifan lingkungan yang akan mendukung keberhasilan pengembangan pariwisata di Yogyakarta. Dengan tersusunnya model kebijakan tersebut, ke depannya diharapkan dapat menjadi pedoman bagi pemerintah dalam mengembangkan kebijakan nasional di bidang pariwisata berkelanjutan pada khususnya serta mendukung kemandirian ekonomi di daerah.
\end{abstract}

Kata Kunci: Ekowisata, Pariwisata, Pariwisata Berkelanjutan 


\section{PENGANTAR}

Pariwisata diposisikan sebagai salah satu sektor andalan dalam pembangunan nasional Indonesia. Saat ini dan pada masa-masa mendatang, pariwisata diharapkan dapat memberikan kontribusi terbesar terhadap peningkatan devisa negara dalam upaya pemerintah mewujudkan kesejahteraan dan kemakmuran rakyat. Salah satu upaya yang dilakukan sektor pariwisata adalah terus meningkatkan kinerjanya dengan meperkuat jejaring yang telah ada dan meningkatkan daya saing usaha pariwisata Indonesia (Astuti, 2008: 89).

Meskipun memberikan manfaat yang besar bagi perkembangan kesejahteraan masyarakat di dunia, pembangunan pariwisata juga sering disebut sebagai salah satu sumber kerusakan lingkungan utama, ketika pembangunan pariwisata tersebut membutuhkan penyediaan infrastruktur yang harus merusak alam sebagaimana yang disebutkan dalam laporan World Tourism Organization tahun 1996. Banyak kasus di beberapa daerah, pembangunan resort dan hotel harus menghancurkan pantai, laut, hutan dan berbagai ekosistem lainnya yang sudah ada dan tumbuh sebelumnya. Keramaian wisatawan juga memberikan dampak perubahan perilaku binatang yang ditunjukkan dengan tingkah agresif yang seringkali membahayakan. Munculnya kawasan kumuh juga menjadi dampak negatif lainnya yang ditimbulkan oleh pariwisata selain masalah perubahan nilainilai budaya lokal akibat masuknya budaya asing (Putra, 2006).

Dilihat dari berbagai laporan, makin berkembangnya pariwisata di Indonesia juga menyisakan banyak kekuatiran, ketika dirasakan pengembangan pariwisata saat ini lebih didominasi oleh nilai-nilai ekonomi dan estetika terkait dengan pengembangan industri, dibandingkan pengembangan nilai-nilai etika budaya, sosial dan kearifan lingkungan dari masyarakat. Sebaliknya pemerintah belum menempatkan tolok ukur keberhasilan pariwisata dari sisi kesejahteraan, partisipasi dan kepuasan masyarakat yang langsung bersentuhan langsung dengan wisatawan.

Masyarakat lokal yang seharusnya menjadi subyek utama di dalam pengelolaan pariwisata, justru menjadi obyek penderita yang diatur dengan berbagai bentuk pengekangan atas nama kepuasan pengunjung. Mengingat hakekat pariwisata itu sendiri lebih luas dari hanya sekedar indikator ekonomi, sudah selayaknya perlu dilakukan interpretasi terhadap kepariwisataan sehingga tidak dimonopoli hanya pada relasi ekonomi semata. Dengan adanya interpretasi tersebut nantinya pariwisata akan tampil dengan lebih dinamis dengan ciriciri pertumbuhan, globalisasi, integrasi, the dialogue between cultures, multidisiplin, sensitivitas dan daya pulih yang merupakan intisari prinsip Global Code of Ethics for Tourism. Karena itu kepariwisataan tidak hanya dilihat sebagai salah satu aktivitas ekonomi, melainkan sebagai sebuah wahana penting untuk pembangunan individu dan manusia (Teguh, 2008:481).

Meskipun memperoleh perhatian khusus dari akademisi pariwisata dan praktisi pembangunan pariwisata beberapa tahun terakhir, namun literatur tentang konsep dan teori pariwisata seringkali gagal menghubungkan pariwisata dengan konsep pembangunan berkelanjutan sebagai kesatuan paradigma, sehingga penerapan pembangunan berkelanjutan dalam konteks pariwisata masih banyak diragukan. Hal ini menimbulkan ketertarikan dunia akademis untuk mendiskusikan konsep pembangunan pariwisata berkelanjutan (Nurhidayati, 2008). Definisi pembangunan pariwisata berkelanjutan dapat memiliki makna beragam. Orang dari banyak bidang yang berbeda menggunakan istilah berbeda di dalam konteks yang berbeda dan mereka mempunyai konsep, bias, dan pendekatan berbeda pula (Sharpley, 2000:1).

Pembangunan pariwisata berkelanjutan, seperti disebutkan dalam Piagam Pariwisata Berkelanjutan (1995) adalah pembangunan yang dapat didukung secara ekologis sekaligus layak secara ekonomi, juga adil 
secara etika dan sosial terhadap masyarakat. Artinya, pembangunan berkelanjutan adalah upaya terpadu dan terorganisasi untuk mengembangkan kualitas hidup dengan cara mengatur penyediaan, pengembangan, pemanfaatan dan pemeliharaan sumber daya secara berkelanjutan.

Hal tersebut hanya dapat terlaksana dengan sistem penyelenggaraan kepemerintahan yang baik (good governance) yang melibatkan partisipasi aktif dan seimbang antara pemerintah, swasta, dan masyarakat. Dengan demikian, pembangunan berkelanjutan tidak saja terkait dengan isu-isu lingkungan, tetapi juga isu demokrasi, hak asasi manusia dan isu lain yang lebih luas. Tak dapat dipungkiri, hingga saat ini konsep pembangunan berkelanjutan tersebut dianggap sebagai resep pembangunan terbaik, termasuk pembangunan pariwisata.

Salah satu bentuk produk pariwisata sebagai turunan dari konsep pembangunan pariwisata yang berkelanjutan adalah konsep pengembangan ekowisata. Ekowisata ini lebih dari sekedar kelompok pecinta alam yang berdedikasi, sebagai gabungan berbagai kepentingan yang muncul dari keperdulian terhadap masalah sosial, ekonomi dan lingkungan. Bagaimana membuat devisa masuk kembali sehingga konservasi alam dapat membiayai dirinya sendiri merupakan inti dari cabang baru ilmu ekonomi hijau pembangunan berkelanjutan ini (Western, 1999;2-3).

Ekowisata menawarkan kesatuan nilai berwisata yang terintegrasi antara keseimbangan menikmati keindahan alam dan upaya melestarikannya. Ekowisata ini dapat berperan aktif di dalam memberikan solusi dalam menyelesaikan permasalahan yang mungkin terjadi dalam pengembangan kawasan pariwisata. Fokus utama dari pengembangan model ekowisata tersebut didasarkan atas potensi dasar kepariwisataan dimana kelestarian alam dan budaya dikedepankan (Dirawan, 2008:139).

Sebagai salah satu tujuan wisata utama di Indonesia, Provinsi Daerah Istimewa Yogyakarta memiliki banyak faktor yang mampu menarik datangnya wisatawan baik domestik maupun manca negara. Faktor keanekaragaman atraksi dan daerah tujuan wisata, di mana terdapat lebih dari 50 tempat tujuan wisata, kemudian faktor atribut budaya, sejarah dan alam yang menjadi ciri khas utama wisata di Yogyakarta dan memberikan identitas yang unik terhadap pariwisata Yogyakarta. Berbagai atribut tersebut dapat menggambarkan pariwisata Yogyakarta secara keseluruhan (Rahajeng, 2008; 33).

Sejalan dengan meningkatnya gerakan pengembangan ekowisata, Pemerintah Yogyakarta juga serius memajukan beberapa potensi pariwisata yang dapat diaplikasikan menjadi konsep ekowisata, seperti pengembangan ekowisata Kaliadem dan Merapi Eco Adventure. Konsep ekowisata tersebut kemudian menawarkan sebuah konsep pariwisata berbasis keindahan alam dan kenyamanan udara Merapi yang dipadukan dengan interaksi masyarakat desa di lereng Merapi, berikut kebudayaan yang dimiliki seperti labuhan sesaji untuk Merapi. Konsep ekowisata lainnya yang dikembangkan adalah konsep ekowisata Kali Code Utara di Kota Yogyakarta. Kali Code Utara sebagai salah satu anak sungai yang langsung terhubung dengan Merapi, menyimpan potensi ekowisata yang berupa wisata pengelolaan sampah mandiri, Ipal komunal serta wisata trecking di sepanjang Kali Code Utara dengan menikmati keindahan arsitektur kali hasil binaan YB. Mangunwijaya (Karomah, 2007;16-18).

Dukungan pemerintah terhadap pengembangan konsep ekowisata di Yogyakarta juga cukup signifikan, salah satunya dalam bentuk Peraturan Walikota Yogyakarta Nomor 17 Tahun 2007 tentang Rencana Pembangunan Jangka Menengah Daerah (RPJMD), yang menerangkan bahwa visi Kota Yogyakarta adalah Kota Pendidikan Berkualitas, Pariwisata Berbasis Budaya dan Pusat Pelayanan Jasa yang Berwawasan Lingkungan.

Definisi dari pariwisata berbasis budaya dalam RPJMD tersebut adalah kegiatan pariwisata harus dikembangkan dengan 
dasar dan berpusat pada budaya Jawa yang selaras dengan sejarah dan budaya Kraton NgaYogyakarta Hadiningrat, kearifan lokal dan nilai-nilai luhur budaya bangsa serta peningkatan kegiatan pariwisata dilaksanakan dengan menciptakan inovasiinovasi yang tetap berlandaskan pada wisata budaya, wisata bangunan bersejarah, wisata pendidikan, wisata konveksi dan wisata belanja.

Sayangnya, seiring dengan modernisasi dan globalisasi ekonomi yang menyebabkan makin meningkatnya tekanan hidup masyarakat, serta tekanan dari peningkatan industri pariwisata yang sudah ada, beberapa kondisi negatif mulai dirasakan di Yogyakarta, baik dari sisi perubahan nilai-nilai budaya, masyarakat maupun penurunan kualitas lingkungan hidupnya.

Dari hasil penelitian Good Goverment on Water Resources Management (GGWRM) Uni Eropa yang bekerjasama dengan Lestari Indonesia dan Walhi Yogyakarta menunjukkan terdapat 266 titik lokasi pembuangan sampah masyarakat ke sungai, yang meliputi aliran sungai BedogBayam, Denggung-Winongo, Belik, Code, Pelang-Gajahwong dan TambakbayanGrojogan Meruwe. Meningkatnya titik lokasi pembuangan sampah masyarakat ke sungai tentu saja menggambarkan meningkatnya ketidakperdulian masyarakat terhadap kebersihan dan kelancaran fungsi sungai itu sendiri.

Berdasarkan pemaparan Badan Lingkungan Hidup (BLH) Provinsi Daerah Istimewa Yoryakarta pada bulan Maret tahun 2011 mengenai profil status dan kondisi lingkungan hidup di Provinsi Daerah Istimewa Yogyakarta dapat dianalisis bahwa dilihat dari status hutan dan lahan, luas hutan yang tersisar sekitar 5,36\% dari luas wilayah yang terdiri dari hutan produksi seluas 13.851,58 Ha, hutan lindung seluas 2.057,90 Ha dan hutan konservasi seluas 910,34 Ha.

Jika dibandingkan dengan kondisi ideal luas hutan di suatu wilayah seharusnya mencapai $30 \%$ dari total luas wilayah, maka kondisi luas hutan di Provinsi Daerah
Istimewa Yogyakarta ini tentu saja jauh di bawah idealnya. Meningkatnya pola perubahan fungsi lahan, penggunaan lahan yang tidak sesuai dengan kemampuan lahan juga menjadi catatan negatif status lingkungan hidup di Provinsi Daerah Istimewa Yogyakarta yang dapat menyebabkan terjadinya kerusakan lahan baik erosi, longsor, kekeringan, lahan kritis, banjir dan sedimentasi.

Dilihat dari status dan kondisi udara di Provinsi Daerah Istimewa Yogyakarta, berdasarkan pemantauan kualitas udara dengan menggunakan metode aktif di 25 titik lokasi dengan parameter yang dipantau meliputi suhu udara, kelembapan, kebisingan, $\mathrm{CO}, \mathrm{HC}$, dan $\mathrm{Pb}$, dari hasil pemantauan terutama parameter kebisingan di beberapa titik, sudah melebihi baku mutu meskipun beberapa parameter lainnya masih berada di bawah baku mutu. Berdasarkan pengamatan yang sama dalam program Urban Air Quality Improvement Program kerjasama antara Indonesia dan Asian Development Bank (ADB), dilaporkan bahwa terjadi peningkatan yang cukup signifikan di dalam faktor pencemaran udara di Provinsi Daerah Istimewa Yogyakarta.

Berbagai gejala perubahan tersebut pada akhirnya dikhawatirkan akan menimbulkan dampak yang cukup signifikan di dalam upaya meningkatkan pertumbuhan pariwisata di Yogyakarta khususnya terkait dengan isu pengembangan pariwisata yang berkelanjutan. Masyarakat yang mengalami pergeseran nilai-nilai budaya, sosial serta memburuknya kualitas lingkungan tentu saja bukan prasyarat yang mendukung upaya pengembangan pariwisata berkelanjutan di Yogyakarta. Dari uraian perumusan permasalahan tersebut, pertanyaan penelitian yang kemudian diajukan adalah: Bagaimana pengembangan model ekowisata berkelanjutan dapat dibentuk di Provinsi Yogyakarta?

Berdasarkan permasalahan tersebut, penelitian ini dilakukan dengan tujuan penelitian untuk merumuskan bentuk pengembangan ekowisata yang berkelan- 
jutan yang dapat menjadi model pariwisata berkelanjutan berbasis nilai-nilai budaya, sosial dan kearifan lingkungan di Yogyakarta.

\section{Pariwisata}

Pariwisata merupakan konsep yang sangat multidimensional layaknya pengertian wisatawan. Tak dapat dihindari bahwa beberapa pengertian pariwisata dipakai oleh praktisi dengan tujuan dan perspektif yang berbeda sesuai dengan tujuan yang ingin dicapai. Sebagai contoh beberapa ahli mendefinisikan pariwisata sebagai berikut:

"Tourism comprises the ideas and opinions people hold which shape their decisions about going on trips, about where to go (and where not to go) and what to do or not to do, about how to relate to other tourists, local and service personnel. And it is all the behavioural manifestations of those ideas and opinions" (Pitana \& Diarta, 2009;45 )

"The activities of persons traveling to and staying in places outside their usual environment for not more than one consecutive year for leisure, business and other purposes" (Pitana \& Diarta, 2009;45)

"The sum of the phenomena and relationships arising from the interactions of tourist, business, host government and host communities in the process of attracting and hosting these tourists and other visitors" (Pitana \& Diarta , 2009;45)

"Tourism is defined as the interrelated system that includes tourist and the associated services that are provided and utilised (facilities, attractions, transportation, and accomodation) to aid in their movement" (Pitana \& Diarta, 2009;45)

Definisi pariwisata memang tidak dapat persis sama di antara para ahli, hal yang memang jamak terjadi dalam dunia akademis, sebagaimana juga dapat ditemui pada berbagai disiplin ilmu lain. Meskipun ada variasi batasan, ada beberapa komponen pokok yang secara umum disepakati di dalam batasan pariwisata yaitu adanya unsur travel, adanya unsur tinggal sementara di tempat yang bukan tempat tinggalnya serta tujuan utamanya bukan untuk mencari penghidupan di tempat yang dituju (Pitana \& Diarta, 2009; 45-47).

Menurut Yoeti (1999;34-35), wisatawan adalah seseorang yang melakukan perjalanan untuk sementara waktu, tidak kurang selama 24 jam, dan ia semata-mata sebagai konsumen, bukan mencari nafkah atau bekerja tetap ditempat yang ia kunjungi. Wisatawan itu adalah orang yang ingin memenuhi kebutuhan setelah kebutuhankebutuhan pokok sudah terpenuhi. Kebutuhan itu antara lain seperti melihat obyek wisata, tata cara hidup masyarakat bangsa lain dan hasil kebudayaannya. Untuk memenuhi kebutuhan wisatawan, maka dilakukan pengembangan di bidang kepariwisataan.

Alasan utama pengembangan pariwisata pada suatu daerah tujuan wisata, baik secara lokal, regional atau ruang lingkup nasional pada suatu negara sangat erat kaitannya dengan pembangunan perekonomian daerah atau negara tersebut. Dengan kata lain, pengembangan kepariwisataan pada suatu daerah tujuan wisata selalu akan diperhitungkan dengan keuntungan dan manfaatnya bagi rakyat banyak. Alasan kedua pengembangan pariwisata itu lebih banyak bersifat non ekonomis, adanya kegiatan kepariwisataan akan menimbulkan hasrat dan keinginan untuk memelihara semua aset wisata yang dimaksud (Yoeti, 1997;33-34).

Dewasa ini hampir seluruh negara di dunia mengakui pariwisata merupakan industri yang mempunyai peran penting dalam menunjang perekonomian nasionalnya. Menurut Richter \& Richter, hampir secara universal pemerintah di dunia menerima pariwisata sesuatu yang positif sehingga sebagian besar kebijakan pariwisata dibuat untuk memperluas industri pariwisata (Hermawan, 2008:17). Selanjutnya ia mengatakan lembaga pemerintah pada setiap tingkat mulai dari internasional sampai ke kota kecil secara berangsur-angsur berperan lebih aktif dalam penggunaan pariwisata sebagai alat pembangunan. 
Hubungan dengan kebudayaan, pariwisata sendiri memiliki banyak tujuan dan salah satunya adalah kebudayaan. Wisatawan secara umum bertujuan berlibur, memanfaatkan waktu untuk mendapat kesenangan. Itulah sebabnya bagi bangsabangsa yang suka berjemur dan berenang, daerah pantai yang indah merupakan daerah tujuan wisata yang populer. Kadang-kadang itu ditambah pula dengan peluang-peluang spa atau pijat yang khas, atau menata rambut jadi kepang kecil-kecil. Atraksi boga dan kesenian juga dapat menjadi nilai tambah bagi suatu daerah wisata. Akan tetapi ekses dari kebebasan berinteraksi antar tamu atau antara tamu dengan tuan rumah itu juga dapat menjuru ke arah pelacuran dan perdagangan narkoba.

\section{Pariwisata Berkelanjutan}

Pengertian pariwisata berkelanjutan adalah: keberlanjutan pariwisata terkait erat dengan kebutuhan wisata saat ini yang tidak boleh mengorbankan dan mengurangi hak dan kebutuhan generasi yang akan datang. Isu pelestarian sumber daya alam dan lingkungan terpampung di dalam kesepakatan bangsa-bangsa di dunia pada KTT Bumi yang diselenggarakan oleh UNCED (United Nation Conference on Environment and Development) yang lebih dikenal sebagai Rio Summit.

Berbagai kesepakatan dalam RioSummit tahun 1992 dievaluasi dalam konferensi Johanesberg tahun 2002 yang mempertegas implementasi pembangunan berkelanjutan di segala bidang. KTT Bumi menghasilkan 5 (lima) butir kesepakatan yang erat kaitannya dengan konservasi sumber daya alam dan lingkungan yang mencakup : Deklarasi Rio, Konservasi Perubahan Iklim, Konservasi Keanekaragaman Hayati, Prinsip-prinsip Kehutanan dan Agenda 21. Prinsip-prinsip dan sasaran-sasaran dari piagam tersebut adalah:

a) Pembangunan pariwisata harus berdasarkan kriteria keberlanjutan dapat didukung secara ekologis dalam waktu yang lama, layak secara ekonomi, adil secara etika dan sosial bagi masyarakat setempat;

b) Pariwisata harus berkontribusi kepada pembangunan berkelanjutan dan diintegrasikan dengan lingkungan alam, budaya dan manusia;

c) Pemerintah dan otoritas yang kompeten dengan partisipasi lembaga swadaya masyarakat dengan masyarakat setempat harus mengambil tindakan untuk mengintegrasikan perencanaan pariwisata sebagai kontribusi kepada pembangunan berkelanjutan;

d) Pemerintah dan organisasi multilateral harus memprioritaskan dan memperkuat bantuan, langsung atau tidka langsung kepada proyek-proyek pariwisata yang berkontribusi kepada perbaikan kualitas lingkungan;

e) Ruang-ruang dengan lingkungan dan budaya yang rentan saat ini maupun di masa depan harus diberi prioritas khusus dalam hal kerja sama teknis dan bantuan keuangan untuk pembangunan pariwisata berkelanjutan. Promosi atau dukungan terhadap berbagai bentuk alternatif pariwisata yang sesuai dengan prinsip-prinsip pembangunan berkelanjutan;

f) Pemerintah harus mendukung dan berpartisipasi dalam penciptaan jaringan untuk penelitian, diseminiasi informasi dan transfer pengetahuan tentang pariwisata dan teknologi pariwisata berkelanjutan;

g) Penetapan kebijakan pariwisata berkelanjutan memerlukan dukungan dan sistem pengelolaan pariwisata yang ramah lingkungan, studi kelayakan untuk transformasi sektor dan pelaksanaan berbagai proyek percontohan dan pengembangan program kerjasama internasional.

\section{Ekowisata}

Indonesia sebagai negara mega biodiversity nomor dua di dunia, telah dikenal memiliki kekayaan alam, flora dan fauna yang sangat tinggi. Para explorer 
dari dunia barat maupun timur jauh telah mengunjungi Indonesia pada abad ke lima belas vang lalu. Perjalanan eksplorasi yang ingin mengetahui keadaan di bagian benua lain telah dilakukan oleh Marcopollo, Washington, Wallacea, Weber, Junghuhn dan Van Steines dan masih banyak yang lain merupakan awal perjalanan antar pulau dan antar benua yang penuh dengan tantangan. Para adventurer ini melakukan perjalanan ke alam yang merupakan awal dari perjalanan ekowisata. Sebagian perjalanan ini tidak memberikan keuntungan konservasi daerah alami, kebudayaan asli dan atau spesies langka (Fandelli, 1993).

Definisi ekowisata yang pertama diperkenalkan oleh organisasi The Ecotourism Society (1990) sebagai berikut: Ekowisata adalah suatu bentuk perjalanan wisata ke area alami yang dilakukan dengan tujuan mengkonservasi lingkungan dan melestarikan kehidupan dan kesejahteraan penduduk setempat. Semula ekowisata dilakukan oleh wisatawan pecinta alam yang menginginkan di daerah tujuan wisata tetap utuh dan lestari, di samping budaya dan kesejahteraan masyarakatnya tetap terjaga.

Akan tetapi, perkembangannya ternyata bentuk ekowisata ini berkembang karena banyak digemari oleh wisatawan. Wisatawan ingin berkunjung ke area alami, yang dapat menciptakan kegiatan bisnis. Ekowisata kemudian didefinisikan sebagai berikut: Ekowisata adalah bentuk baru dari perjalanan bertanggungjawab ke area alami dan berpetualang yang dapat menciptakan industri pariwisata (Fandeli, 2000). Dari kedua definisi ini dapat dimengerti bahwa ekowisata dunia telah berkembang sangat pesat.

Ternyata beberapa destinasi dari taman nasional berhasil dalam mengembangkan ekowisata ini. Bahkan di beberapa wilayah berkembang suatu pemikiran baru yang berkait dengan pengertian ekowisata. Fenomena pendidikan diperlukan dalam bentuk wisata ini. Hal ini seperti yang didefinisikan oleh Australian Department of Tourism (Fandeli, 2000) yang mendefinisikan ekowisata adalah wisata berbasis pada alam dengan mengikutkan aspek pendidikan dan interpretasi terhadap lingkungan alami dan budaya masyarakat dengan pengelolaan kelestarian ekologis. Definisi ini memberi penegasan bahwa aspek yang terkait tidak hanya bisnis seperti halnya bentuk pariwisata lainnya, tetapi lebih dekat dengan pariwisata minat khusus, alternative tourism atau special interest tourism dengan obyek dan daya tarik wisata alam.

Definisi lainnya mengenai ekowisata, seperti yang diuraikan oleh Green Tourism Association, adalah suatu pembangunan pariwisata yang memiliki empat pilar atau atribut yaitu;

a) Environmental responsibility; mengandung pengertian proteksi, konservasi atau perluasan sumber daya alam dan lingkungan fisik untuk menjamin kehidupan jangka panjang dan keberlanjutan ekosistem, misalnya wisata alam Ujung Kulon yang akan menghasilkan sebuah konsep ekosistem berkelanjutan dari satwa badak bercula;

b) Local economic vitality; mendorong tumbuh dan berkembangnya ekonomi lokal, bisnis dan komunitas untuk menjamin kekuatan ekonomi dan keberlanjutan (sustainability) misalnya dampak dari pembangunan lokasi wisata biasanya akan diikuti oleh maraknya kegiatan ekonomi lokal ;

c) Cultural sensitivity; mendorong timbulnya penghormatan dan apresiasi terhadap adat istiadat dan keragaman budaya untuk menjamin kelangsungan budaya lokal yang baik misalnya melalui wisata budaya, maka orang akan mengenal budaya daerah atau negara lain dan menimbulkan penghormatan atas kekayaan budaya tersebut ;

d) Experiental richness; menciptakan atraksi yang dapat memperkaya dan meningkatkan pengalaman yang lebih memuaskan, melalui partisipasi aktif dalam memahami personal dan keterlibatan dengan alam, manusia, tempat dan/atau budaya (Yoeti, 2006;26). 
Jenis penelitian yang dilakukan adalah penelitian Kausal Komparatif (Causal Comparative Research) yakni jenis penelitian yang bertujuan mencari kemungkinan hubungan sebab akibat dengan cara mengamati akibat yang sekarang ada dan mencoba mencari kemungkinan penyebabnya dari data yang dikumpulkan. Hubungan sebab akibat yang akan dianalisis adalah perubahan nilai-nilai budaya, sosial, lingkungan sebagai sebab yang menimbulkan dampak bagi kegiatan pariwisata berupa gejala perkembangan pariwisata yang tidak berkelanjutan di Provinsi Daerah Istimewa Yogyakarta sebagai akibatnya.

Tempat yang dipilih sebagai lokasi penelitian adalah Provinsi Yogyakarta dengan responden berbagai pelaku budaya, tokoh masyarakat, wisatawan serta pihakpihak yang terkait dengan kegiatan pengembangan pariwisata berkelanjutan, untuk mendapatkan gambaran mengenai nilai-nilai budaya, sosial dan kearifan lingkunganyangmendukung pengembangan pariwisata berkelanjutan di Yogyakarta.

Sebagai sampel penelitian dipilih 3 desa wisata yaitu Desa Wisata Sambi, Desa Wisata Kebon Agung dan Desa Wisata Brayut. Hasil dari wawancara tersebut digunakan sebagai salah satu dasar penilaian untuk mengevaluasi dan mengkaji pelaksanaan wisata berkelanjutan di Yogyakarta sekaligus konfirmasi kepada wisatawan melalui instrumen kuesioner terstruktur untuk mendapatkan gambaran mengenai persepsi mereka terkait dengan pelaksanaan ekowisata di Yogyakarta sekaligus kesediaan berpartisipasi di dalam pengembangan ekowisata tersebut.

Teknik pengambilan sampel yang digunakan dalam penelitian ini adalah metode accidental sampling (non-probability sampling). Metode tersebut dipilih dengan mempertimbangkan faktor ukuran populasi atau sampel tidak diketahui karena peneliti tidak mengetahui siapa saja yang akan menjadi pengunjung lokasi wisata karena bersifat non-probability sampling, maka penelitian ini tidak dapat menggeneralisasi suatu kesimpulan umum.
Teknik pengumpulan data dilakukan dengan menggunakan metode wawancara mendalam dengan berbagai informan penelitian yang nantinya akan dianalisis dengan menggunakan metode content analysis untuk mendapatkan gambaran mengenai proses perubahan sosial, budaya dan lingkungan di Yogyakarta terkait dengan pengembangan pariwisata berkelanjutan.

Penelitian ini sebagian besar mendasarkan kepada pendekatan kualitatif untuk menggambarkan proses pengembangan pariwisata di Provinsi Daerah Istimewa Yogyakarta. Pendekatan kualitatif juga di lakukan untuk kepentingan eksplorasi informasi dari seluruh pihak yang bertanggungjawab di dalam melaksanakan kegiatan pariwisata.

Variabel yang menjadi indikator utama dalam penelitian ini adalah variabel nilainilai budaya, sosial dan kearifan lingkungan di Provinsi Daerah Istimewa Yogyakarta, yang nantinya akan menjadi salah satu bahan analisis dengan mendasarkan teori, hingga nantinya dapat disusun menjadi sebuah model pengembangan ekowisata berkelanjutan.

\section{PEMBAHASAN}

Sesuai dengan amanat Rencana Pembangunan Jangka Menengah Daerah (RPJMD) Provinsi Yogyakarta, yang menerangkan bahwa visi Yogyakarta adalah Pendidikan Berkualitas, Pariwisata Berbasis Budaya dan Pusat Pelayanan Jasa yang Berwawasan Lingkungan. Definisi dari pariwisata berbasis budaya dalam RPJMD tersebut adalah kegiatan pariwisata harus dikembangkan dengan dasar dan berpusat pada budaya Jawa yang selaras dengan sejarah dan budaya Kraton NgaYogyakarta Hadiningrat, kearifan lokal dan nilai-nilai luhur budaya bangsa serta peningkatan kegiatan pariwisata dilaksanakan dengan menciptakan inovasi-inovasi yang tetap berlandaskan pada wisata budaya, wisata bangunan bersejarah, wisata pendidikan, wisata konveksi dan wisata belanja.

Kebudayaan ini juga menjadi aspek keunggulan utama dari pengembangan pariwisata di Yogyakarta dibandingkan 
dengan pariwisata di daerah lain. Pola pembangunan yang berkelanjutan, pada intinya harus didasarkan kepada pelaksanaan pemenuhan tiga aspek utama yaitu aspek keberlanjutan ekologi, keberlanjutan sosial dan keberlanjutan ekonomi. Sedangkan sebuah daerah wisata dikategorikan sebagai ekowisata, sesuai dengan kriteria dari Green Tourism Organization, daerah wisata tersebut harus memenuhi kriteria environmental reponsibility, local economic vitality, cultural sensitivity, dan experiental richness.

Jika disandingkan, pada dasarnya pengembangan pilar-pilar ekowisata berdasarkan Green Tourism Organization tersebut dapat sekaligus menjawab permasalahan pembangunan berkelanjutan. Aspek keberlanjutan ekologi dapat dijawab dengan pilar environmental responsibilities, kemudian pilar local economic vitality, cultural sensitivity dan experiental richness merupakan jawaban atas tujuan pembangunan sosial. Lebih detailnya pilar local economic vitality juga menjawab permasalahan pembangunan ekonomi. Secara langsung persandingan antara kriteria Ekowisata dengan aspek Pembangunan Berkelanjutan dapat diamati pada diagram di bawah ini:

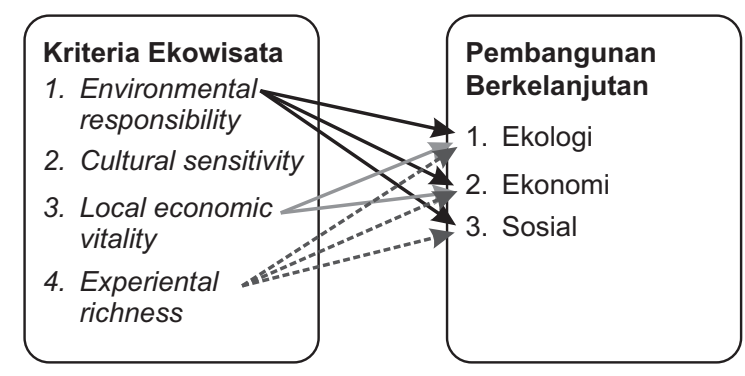

Gambar 4.1.

Persandingan Antara Kriteria Ekowisata dan Pembangunan Berkelanjutan

Desa Kebonagung merupakan Desa yang terletak di bagian selatan Daerah Istimewa Yogyakarta, tepatnya di Kecamatan Imogiri, Kabupaten Bantul. Luas Desa ini sekitar 183,1105 hektar yang terdiri dari 5 pedukuhan yaitu Pedukuhan Jayan, Kalangan, Kanten, Mandingan dan Tlogo. Dari ke 5 pedukuhan tersebut, dibagi lagi menjadi Rukun Tetangga (RT) yang mencapai 23 RT.
Desa Wisata Kebonagung didirikan dan dikembangkan berdasarkan Surat Keputusan Bupati Bantul Nomor 359 tahun 2006 tentang Kepengurusan Pokdarwis Desa Kebonagung, Kecamatan Imogiri. Visi yang dikembangkan di Desa Wisata Kebonagung adalah visi terwujudnya Desa Wisata mandiri, meningkatnya pendapatan masyarakat dan pengelola untuk kesejahteraan bersama. Sedangkan misi yang dikembangkan meliputi; terbangunnya sarana dan prasarana pendukung, optimalisasi SDA dan SDM, menguatkan lembaga pengelola, meningkatkan promosi dan pelayanan tamu.

Dasar pemikiran awal berdirinya Desa Wisata Kebonagung adalah keyakinan bahwa potensi yang ada di Kebonagung dapat dikembangkan, program yang dijalankan pasti bermanfaat bagi masyarakat dan pengelola, mendapat dukungan dari masyarakat dan pemerintah, mengemas potensi yang ada, hak dan kewajiban masyarakat dan pengelola jelas, serta dipastikan memiliki pangsa pasar.

Dari hasil analisis ternyata keseluruhan stakeholder yang terlibat perrguruan tinggi, pemilik homestay, masyarakat desa, pemerintah daerah dan pengunjung memiliki peran yang signifikan di dalam membentuk sebuah rantai keberhasilan pelaksanaan Desa Wisata Kebonagung. Perguruan tinggi sebagai sebuah institusi pendidikan memiliki peran dan tanggungjawab di dalam meningkatkan kapasitas dan kemampuan teknik dari masyarakat dan pengelola Desa Wisata Kebonagung. Peran yang sama juga diberikan kepada Pemda yang dapat berfungsi sebagai fasilitator sekaligus pendukung utama jalannya Desa Wisata Kebonagung melalui berbagai kebijakan yang akan dihasilkannya.

Jenis-jenis pertunjukan yang ditawarkan di Desa Wisata Kebonagung sendiri terdiri dari;

(1) Pertunjukan Pendidikan Pertanian yang terdiri dari kegiatan membajak, menggaru, menanam menuju sebuah pendidikan pertanian organik sebagai ciri utama dari Desa Wisata Kebonagung; 
(2) Pertunjukan Kesenian Budaya dalam bentuk kesenian Jathilan, Gejog Lesung Tradisional, gejog Lesung Kolaborasi, Karawitan, Ketoprak dan Cokekan;

(3) Pertunjukan Seni Kerajinan seperti membatik lukis, gerabah cetak, gerabah putar, mewarnai gerabah serta menjanur;

(4) Pertunjukan Kuliner Tradisional seperti pembuatan apem, cemplon, mendoan, onde-onde, gula kelapa, obat anget dan paket kenduri;

(5) Pertunjukan Wisata Sepeda Onthel menuju makam-makan Imogiri, sentra peyek, kerajinan keris dan berkeliling desa;

(6) Pertunjukan Wisata Air Bendung Tegal untuk kegiatan perahu naga dan wisata air lainnya;

Untuk mendukung pelaksanaan wisata yang ramah lingkungan, perduli dengan pelastarian alam dan budaya, Desa Wisata Kebonagung juga menawarkan konsep wisata menginap dan berinterkasi langsung dengan warga masyarakat desa. Tersedia sekitar 22 rumah, masyarakat desa yang telah dipilih sesuai dengan kriteria tertentu (kondisi MCK, jendela, pintu, kebersihan lingkungan, sirkulasi udara dan lainnya) dengan berbagai jenis rumah dan tipe seperti.

Di Desa Wisata Brayut, kondisi sebagian besar tanah produktif masih difungsikan untuk lahan pertanian dengan luas wilayah sekitar 34.750 hektar, sedangkan 4 hektar terdiri dari tanah pekarangan dan permukiman penduduk. Kondisi ekonomi masyarakat cukup baik, terlihat dari keadaan rumah tempat tinggal, tingkat pendidikan masyarakat dan lingkungan tertata rapi dan bersih. Rumah-rumah didusun Brayut pada umumnya berbentuk rumah sinom dan joglo sebagai ciri kas rumah Jawa tempo dulu.

Dilihat dari banyaknya rumah joglo dan sinom di dusun ini merupakan bukti bahwa Brayut dihuni sudah cukup lama. Jalan menuju dusun ini beraspal cukup baik, kendaraan bus pun sudah dapat sampai dilokasi, sedangkan jalan lingkungan pemukiman telah diperkeras dengan conblok sepanjang 1000 meter dengan biaya swadaya masyarakat setempat, dengan demikian akan mempermudah transportasi masyarakat terutama beraktivitas membawa hasil bumi.

Hamparan sawah yang luas dan subur masih dapat dijumpai, ketika musim kemarau tiba para petanipun masih dapat mengolah sawahnya dengan berbagai jenis tanaman, air tidak menjadi masalah bagi masyarakat Brayut. Sumber mata air yang berada disebelah dusun mampu memberikan kontribusi bagi penduduk sepanjang tahun, baik dimanfaatkan untuk pertanian, peternakan maupun kolam pemancingan. Masyarakat masih berharap banyak dari keadaan alam sekitar ini sebagai penopang hidup. Alam dengan hamparan sawah dan panorama gunung merapi dapat dilihat di dusun Brayut ini, disamping ada beberapa tempat bersejarah tinggalan masyarakat setempat di antaranya :

(1) Pertunjukan wisata jalan-jalan; menelusuri dan mengelilingi dusun Brayut;

(2) Pertunjukan belajar mengolah sawah atau bercocok tanam serta menggunakan alat pertanian berupa ani-ani;

(3) Pertunjukan menginap di Home Stay atau Joglo;

(4) Pertunjukan paket belajar bahasa jawa, membatik, merangkai janur, memasak makanan Khas, menari kesenian lokal;

(5) Seni Budaya; kehidupan masyarakat Brayut masih melestarikan seni budaya warisan nenek moyang terutama dengan seni karawitan dimana kesenian ini bagi masyarakat Jawa bukan hal yang baru, walaupun tidak semua dusun memiliki kelompok atau group karawitan, disamping seni gamelan, masyarakatnya memiliki seni tari klasik dan sholawatan;

(6) Pertunjukan Tradisional; yang terdiri dari berbagai jenis makanan legondo, sagon dan klepon;

(7) Pertunjukan Pengolahan Limbah Ternak; limbah ternak yang berpotensi menimbulkan pencemaran lingkungan sudah dapat didaur ulang di Desa 
Wisata Brayut, bahkan menjadi salah satu atraksi yang ditawarkan kepada pengunjung berupa pengolahan limbah ternak menjadi biogas yang dimanfaatkan untuk penerangan desa serta memasak di rumah warga;

(8) Upacara Daur Hidup; pada waktu tertentu saat musim panen, atau kegiatan upacara ritual dalam rangkaian peringatan atas kematian seseorang anggota keluarga dari mulai membuat liang lahat mengadakan selamatan kenduri. Sedangkan upacara wiwit merupakan bentuk tradisi menyampaikan rasa syukur pada Tuhan Yang Maha Esa bahwa padi telah dapat dipanen.

DesaWisataSambiterletakdipedukuhan Dusun Sambi, Desa Pakem Binangun, Kecamatan Pakem, Kabupaten Sleman, Jln. Kaliurang Km 19,5 arah utara Yogyakarta menuju obyek wisata Kaliurang luas wilayah 25,4 ha. Dapat ditempuh dengan kendaraan bermotor lebih kurang 30 menit dari pusat kota. Desa ini merupakan kawasan yang masih berdekatan dengan Gunung Merapi, kondisi alamnya merupakan dataran lereng Merapi dan dengan terdapatnya aliran Sungai Kuning dengan sumber mata air pegunungan, sehingga Dusun Sambi masih terasa berhawa sejuk.

Desa Wisata Sambi memiliki beragam potensi wisata yang menarik untuk dikunjungi oleh wisatawan. Desa wisata yang berada cukup dekat dengan Gunung Merapi ini menghadirkan panorama alam yang sangat indah untuk dinikmati sehingga dapat memberikan kesegaran dan ketentraman hati, panorama alam pesawahan dan pepohonan yang rindang serta kejernihan airnya juga rumah-rumah adat seperti joglo, limasan, simon, dengan halaman yang luas, dapat dipakai media bermain sambil menikmati sejuknya udara serta suasana desa alami asli Yogyakarta.

Adapun potensi atraksi wisata yang ditawarkan oleh Desa Wisata Sambi terdiri dari;
(1) Pertunjukan panorama desa; dimana panorama desa yang sejuk, asri dan nyaman dapat menjadi daya tarik tersendiri bagi pengunjung Desa Wisata Sambi. Pengunjung dapat berjalan menyusuri desa (tracking) dengan dipanduolehpemandu setempat, dengan model dari tracking dapat disesuaikan dengan kebutuhan pengunjung;

(2) Pertunjukan pertanian; lahan pertanian yang membentang di Desa Wisata Sambi merupakan obyek yang menarik. Pengunjung dapat merasakan secara langsung kegiatan pertanian seperti menanam padi, mambajak sawah dan belajar budidaya jamur;

(3) Pertunjukan peternakan; di mana peternakan desa wisata sambi sebetulnya adalah peternakan sapi perah. Pengujung dapat mempraktekan cara memerah susu sapi secara tradisional. Pengunjung juga dapat membudidayakan sapi perah, selain menangkap ikan di sawah tanpa menggunakan alat sama sekali;

(4) Pertunjukan outbond; di mana jenis atraksi ini dipusatkan Ledok Sambi yang lokasinya dekat dengan Kali Kuning. Fasilitas yang dimiliki oleh Ledok Sari meliputi flying fox, meniti tali dan lain-lain;

(5) Pertunjukan kesenian; Desa Wisata Sambi memiliki berbagai jenis kesenian masyarakat antara lain wayang kulit, karawitan, uyon-uyon dan lain-lain. Selain melihat pertunjukan kesenian tersebut, pengunjung dapat mempelajari kesenian tersebut;

(6) Pertunjukan kebudayaan; berupa kenduri, sadranan dan ruwahan;

(7) Pertunjukan rumah Joglo dan Homestay; rumah Joglo yang terdapat di dusun Sambi dibangun pada tahun 1952 dan sampai sekarang belum pernah mengalami pemugaran atau renovasi. Wisatawan dapat menginap di homestay rumah-rumah penduduk sekitar sehingga dapat berinteraksi langsung dengan masyarakat. 
Berdasarkan analisis berbagai bentuk dan tipe pengelolaan pariwisata yang ada di Yogyakarta dewasa ini, peneliti menilai bahwa tipe pengelolaan pariwisata berbasis berbasis komunitas, dalam hal ini berbentuk Desa Wisata, merupakan tipe pengelolaan pariwisata yang dapat direkomendasikan sebagai Model Pengembangan Pariwisata yang Berkelanjutan di Yogyakarta sebagai bentuk implementasi dari konsep ekowisata. Diharapkan nantinya model tersebut dapat dijadikan dasar pemikiran di dalam penyusunan kebijakan pengembangan pariwisata di Yogyakarta pada khususnya dan nasional pada umumnya.

Dari berbagai hasil analisis mendalam dan kunjungan lapangan langsung ke beberapa Desa Wisata yang ada dan tumbuh di Provinsi Daerah Istimewa Yogyakarta, Desa Wisata yang benar-benar memenuhi aspek dan kriteria ekowisata yang akan menghasilkan konsep pariwisata berkelanjutan di Yogyakarta adalah Desa Wisata Kebonagung di Kabupaten Bantul, Desa Wisata Brayut di Kabupaten Sleman dan Desa Wisata Sambi di Kabupaten Sleman. Kesimpulan tersebut berdasarkan hasil analisis teori ekowisata serta hasil diskusi mendalam dengan seluruh pengelola serta masyarakat di tiga Desa Wisata yang menjadi sampel penelitian baik di Desa Wisata Kebonagung, Sambi dan Brayut. Hasil dari analisis tersebut dapat diuraikan sebagai berikut;

(1) Masing-masing Desa Wisata tersebut memiliki tujuan mengembangkan jenis pariwisata alternatif dari berbagai jenis pariwisata yang sudah ada di Yogyakarta. Desa Wisata tersebut menawarkan konsep berwisata tinggal dan menetap sementara waktu (live in) dengan masyarakat desa secara langsung. Periode menetap sementara waktu sangat disesuaikan dengan kebutuhan dan keinginan dari wisatawan, dimana biasanya kisaran waktu tinggal sementara wisatawan antara tiga hingga enam hari. Adanya konsep tinggal sementara waktu bersama dengan masyarakat ini merupakan bentuk implementasi dari upaya penguatan ekonomi lokal secara mandiri sesuai dengan pilar local economic vitality;

(2) Selama menetap bersama dengan masyarakat, wisatawan akan hidup berdampingan secara normal dengan aktivitas masyarakat desa, sehingga diharapkan wisatawan akan dapat merasakan secara langsung bagaimana aktivitas masyarakat desa berjalan setiap harinya sekaligus mempelajari konsep kekerabatan sosial, kekayaan budaya serta kearifan lingkungan yang dimiliki oleh masyarakat di masingmasing Desa Wisata tersebut sebagai impelementasi dari pilar environmental responsibility serta cultural sensitivity;

(3) Masing-masing Desa Wisata juga menawarkan berbagai bentuk pertunjukan kepada wisatawan yang menggambarkan kekayaan budaya, kearifan sosial dan kearifan lingkungan Desa Wisata. Kegiatan pertunjukan tersebut selain memberikan aspek pendapatan income bagi masyarakat sekaligus sebagai upaya pelestarian nilai-nilai budaya, sosial dan kearifan lingkungan yang menggambarkan berjalannya pilar environmental reponsibility, cultural sensitivity, local economic vitality serta experiental richness;

(4) Di masing-masing Desa Wisata tersebut, kegiatan pariwisata bukan menjadi pekerjaan utama mereka. Pada dasarnya masyarakat di masing-masing Desa Wisata tersebut sudah memiliki status pekerjaan utama, mayoritas sebagai petani, sebagian menjadi pedagang, sebagian lagi berstatus wiraswasta, ada pula yang menjadi guide wisata di kota, tukang bangunan, tukang tambal ban dan segala jenis pekerjaan lainnya. Meskipun jika dilihat dari sisi kesejahteraan nominal, hampir semua status pekerjaan masyarakat tersebut masih jauh dari standar masyarakat kaya, tetapi hampir semua masyarakat 
di Desa Wisata tersebut merasa sejahtera karena desanya aman, harmonis, tidak ada persaingan, tidak ada konflik.

Kesejahteraan non ekonomi itulah yang pada gilirannya akan menjadikan masyarakat merasa senang, gembira menjalankan pariwisata di Desa Wisata masing-masing, karena mereka justru berharap dengan adanya Desa Wisata tersebut, keeratan masyarakat, sikap tolong menolong, saling menghargai dan membantu serta berbagai sikap positif lainnya akan semakin kuat terbangun di kalangan masyarakat desa. Sama sekali tidak terbersit adanya orientasi kepada perhitungan profit ekonomi semata, karena yang ada di benak masyarakat dan pengelola adalah bagaimana cara mereka maju bersama-sama dengan adanya Desa Wisata ini. Jika nantinya Desa Wisata mereka menjadi tidak laku, atau kalah bersaing dengan Desa Wisata lainnya, mereka akan bertransformasi kembali menjadi masyarakat desa biasa dengan status pekerjaan utama mereka, atau justru menjadi masyarakat dengan status baru mereka non pariwisata;

Jadi di sinilah sebetulnya letak kekuatan utama dari 3 (tiga) Desa Wisata yang dijadikan sampel di mana mereka memandang kegiatan wisata di Desa mereka sebagai sebuah kegairahan, sebuah upaya bersama untuk memberikan berbagai benefit non ekonomi bagi perkembangan Desa. Masyarakat lebih erat, lebih saling menghargai, lebih saling menghormati, sejahtera bersama-sama adalah indikator-indikator yang menurut mereka lebih penting dibandingkan sekedar indikatorindikator ekonomi semata dalam bentuk tingkat keuntungan, tingginya tingkat hunian, tingginya daya saing Desa mereka, karena jika di 3 (tiga) Desa Wisata sampel tersebut kelebihan pengunjung yang menginap, dengan sukarela akan diberikan kepada Desa Wisata tetangganya, atau misalnya dengan mudah rombongan pengunjung dapat melakukan negosiasi kesepakatan harga menginap di rumah masyarakat jika memang rombongan pengunjung tersebut memiliki keterbatasan anggaran.
Berdasarkan input tipe pengelolaan wisata berbasis komunitas dalam bentuk Desa Wisata yang terpilih, rekomendasi kebijakan pengelolaan pariwisata yang berkelanjutan di Provinsi Daerah Istimewa Yogyakarta pada khususnya dan nasional pada umumnya dapat disusun dalam sebuah Model Pengembangan Pariwisata Berkelanjutan sebagai berikut:

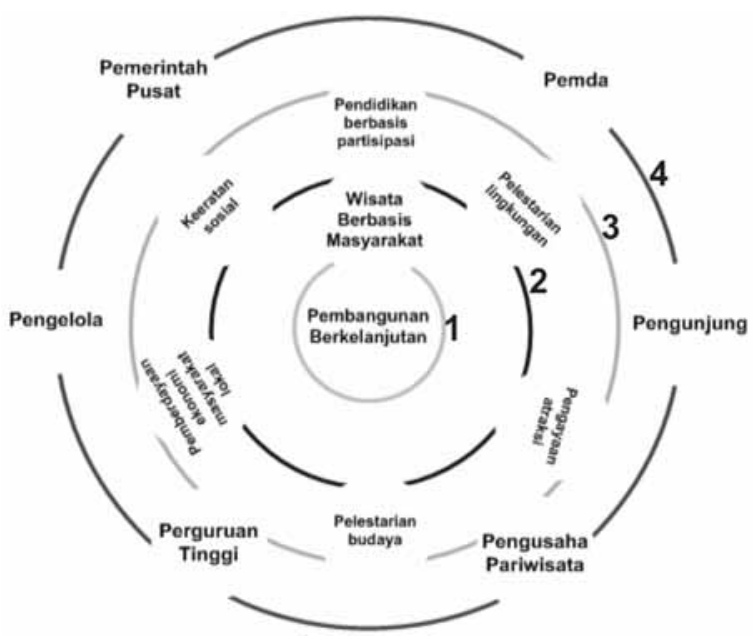

Gambar 4.2

Model Pengembangan Ekowisata Berkelanjutan

Model inilah nantinya yang diharapkan dapat diterapkan sebagai sebuah kebijakan bagipengembangan pariwisata berkelanjutan bukan hanya di Yogyakarta, melainkan di seluruh wilayah di Indonesia khususnya di daerah-daerah tujuan utama wisata. Model Pengembangan Ekowisata Berkelanjutan tersebut nantinya akan disusun berdasarkan penggolongan 4 (empat) Elemen yaitu;

(1) Menjadikan isu Pembangunan Berkelanjutan sebagai visi dan tujuan utama dari pola pengembangan dan pengelolaan wisata, disebut sebagai Elemen Utama;

(2) Berbentuk wisata yang berbasis masyarakat sebagai Elemen Produk Pariwisata;.

(3) Memiliki pilar pelestarian lingkungan, pelestarian budaya, pengayaan atraksi, pendidikan berbasis partisipasi, keeratan masyarakat, dan pemberdayaan ekonomi masyarakat lokal sebagai Elemen Kriteria; 
(4) Didukung sepenuhnya oleh seluruh stakeholders dan stakeholder baik masyarakat, pengunjung, pengelola, perguruan tinggi, pemerintah pusat, pemerintah daerah maupun pengusaha pariwisata sebagai Elemen Pendukung.

Seluruh daerah wisata di Indonesia diharapkan mampu mengaplikasikan Model Pengembangan Ekowisata Berkelanjutan ini di dalam implementasi pengelolaan wisatanya. Tanpa memandang apakah wisata tersebut dilaksanakan di desa atau di kota, apakah berbasis keindahan alam atau kekayaan budaya, apakah dilaksanakan oleh Pemda atau dilakukan oleh swasta, dengan mendasarkan pengelolaan kepada keseluruhan elemen tersebut, diharapkan mampu mewujudkan keberlanjutan dari pengembangan pariwisata dalam konteks apapun, tentu saja dengan penyesuaian beberapa asumsi yang mendasar misalnya disesuaikan dengan adat dan nilai-nilai yang berlaku atau disesuaikan dengan tingkat kesiapan dari daerah itu sendiri.

Satu hal yang harus selalu menjadi dasar pertimbangan pengambilan kebijakan adalah adanya aspek hirarki dan saling keterkaitan di antara keseluruhan elemen yang ada di dalam model pengelolaan tersebut. Artinya visi dan tujuan utama dari aspek pembangunan berkelanjutan adalah hal yang paling esensial yang tidak dapat ditawar-tawar lagi. Begitu visi dan tujuan pembangunan berkelanjutan sudah ditetapkan, elemen lainnya akan mulai berfungsi saling berkaitan karena visi dan tujuan tersebut dapat diimplementasikan dalam kerangka pariwisata berkelanjutan jika produk pariwisata yang dijalankan adalah wisata berbasis masyarakat. Dengan menjalankan wisata berbasis masyarakat secara otomatis keseluruhan pilar-pilar akan dapat diwujudkan di masyarakat. Keseluruhan proses tersebut akan dapat berjalan jika seluruh pihak yang berkepentingan akan memberikan dukungan sesuai dengan fungsi dan peran masingmasing.

\section{SIMPULAN}

Bentuk dan tipe pengelolaan wisata berbasis masyarakat dalam bentuk Desa Wisata adalah bentuk pariwisata yang dapat menjadi Model Pengembangan Ekowisata Berkelanjutan di Yogyakarta secara khusus dan nasional secara umum;

Model Pengembangan Ekowisata Berkelanjutan nantinya akan disusun berdasarkan penggolongan 4 (empat) Elemen yaitu;

Pertama, menjadikan isu Pembangunan Berkelanjutan sebagai visi dan tujuan utama dari pola pengembangan dan pengelolaan wisata, disebut sebagai Elemen Utama;

Kedua, berbentuk wisata yang berbasis masyarakat sebagai Elemen Produk Pariwisata;

Ketiga, Memiliki pilar pelestarian lingkungan, pelestarian budaya, pengayaan atraksi, pendidikan berbasis partisipasi, keeratan masyarakat, dan pemberdayaan ekonomi masyarakat lokal sebagai Elemen Kriteria;

Keempat, Didukung sepenuhnya oleh seluruh stakeholders dan shareholder baik masyarakat, pengunjung, pengelola, perguruan tinggi, pemerintah pusat, pemerintah daerah maupun pengusaha pariwisata sebagai Elemen Pendukung. Rekomendasi bagi Pemda; menjadikan Model Pengembangan Ekowisata Berkelanjutan yang terdiri dari empat elemen utama sebagai konsep dasar pengembangan pariwisata di daerah ke depannya. Rekomendasi bagi Pemerintah Pusat: penetapan Model Pengembangan Ekowisata Berkelanjutan ini sebagai input di dalam penyusunan master plan pengembangan pariwisata nasional sekaligus pemberian bantuan pendanaan infrastruktur. Rekomendasi bagi Perguruan Tinggi: meningkatkan pola kerjasama antara lokasi wisata dengan mahasiswa. Wisata dapat berfungsi sebagai media pendidikan langsung berbasis partisipasi.Rekomendasi bagi pengusaha pariwisata: untuk lebih memberikan pemahaman bahwa indikator kesuksesan wisata tidak selalu hal yang sifatnya ekonomi semata; 


\section{DAFTAR PUSTAKA}

Butler, R.W.,1975, “Tourism as An Agent of Social Change, Tourism as a Factor in National and Regional Development" Occasional Paper 4 Peterborough Ontario Department of Geography Trent University.

Ben-Akiva, Moshe, \& Steven, R. Lerman, 1985, “Discrete Choice Analysis: Theory and Application to Travel Demand" The MIT Press.

Freeman III, A. Myrick,1993, “The Measurement of Environmental and Resources Values: Theory and Methods" Washington, D.C.

Creswell, John W, 2003, "Research Design Qualitative, Quantitative and Mixed Methods Approaches "Sage Publication Inc. United Kingdom.

Arianto, Agus, 2004, “Upaya Pemerintah Kabupaten Pacitan Dalam Upaya Pelestarian Budaya Cepotran (Studi Kasus Dinas Kebudayaan dan Pariwisata Kabupaten Pacitan)" Skripsi Jurusan Ilmu Pemerintahan FISIP UMM.

Gidden, Anthony, 2004, "TeoriStrukturasi Untuk Analisis Sosial" Topprint Yogyakarta.

Afri, Listian, 2005, “Pengaruh Obyek Wisata Candi Borobudur Terhadap Perilaku Sosial Ekonomi Pedagang di Kawasan Taman Wisata Candi Borobudur Kabupaten Magelang" Skripsi Sarjana Pendidikan Pacasila dan Kewarganegaraan Universitas Negeri Semarang.

Bukhari, Zahraini, 2005, "Strategi Pengembangan Budaya Melayu Unggulan di Kabupaten Bengkalis" Tugas Akhir. Program Studi Manajemen Pembangunan Daerah Sekolah Pasca Sarjana IPB.

Iamtrakul, Pawinee, Kardi Teknomo \& Kazunori Hokao, 2005, "Public Park Valuation Using Travel Cost Method" Proceedings of the Eastern Asia Society for Transportation Studies, Vol. 5, pp. 1249-1264.
Damanik, Janianton \& Helmut F. Weber, 2006, "Perencanaan Ekowisata; Dari Teori ke Aplikasi" Kerjasama Pusat Studi Pariwisata UGM \& Penerbit Andi, Yogyakarta.

Dirawan, Gurfan Darma, 2006, “Strategi Pengembangan Ekowisata (Studi Kasus Suaka Margasatwa Mampie Lampoko)" Jurnal Kepariwisataan Indonesia Jakarta.

Hasanudin, 2006, "Konflik Kepariwisataan di Padang Pariaman" Draft Artikel Ilmiah Penelitian Dosen Muda Fakultas Sastra Jurusan Sastra Daerah, Universitas Andalas.

Himooned, Twaambo, 2007, “Opportunities and Constraint of Local Participation in Ecotourism; Case Study of Kasanka National Park (KNP) Zambia" Tesis in Development Studies Norwegian University of Science and Technology.

Karomah, Prapti, Marwati \& Kapti Asiatun, 2007, "Kesiapan Masyarakat Code Untuk Meningkatkan Kecapaka Hidup Dengan Memanfaatkan Limbah Industri Sebagai Cinderamata Khas Yogyakarta "Jurnal Penelitian Bappeda Kota Yogyakarta, No 2 Desember.

Binarwan,Robby, 2008, "Pengembangan Pariwisata Berbasis Masyarakat di Obyek Wisata Ciater Jawa Barat" Jurnal Kepariwisataan Indonesia Departemen Kebudayaan dan Pariwisata Indonesia, vol. 3 No 4 Desember,3-5.

Baskoro, BRA \& Cecep Rukendi, 2008, "Membangun Kota Pariwisata Berbasis Komunitas; Sebuah Kajian Teoritis" Jurnal Kepariwisataan Indonesia Departemen Kebudayaan dan Pariwisata Indonesia, vol. 3 No 1 Maret, 5-7.

Chaerun Nisa, Muliani, 2008, “Pengaruh Aktivitas Pariwisata Terhadap Keberlanjutan Sumberdaya Wisata Pada Obyek Wisata PAI, Kabupaten 
Tegal" Tugas Akhir. Jurusan Perencanaan Wilayah dan Kota Undip.

Hadi, Abdul.W.M, 2008, “Takdir Alisyahbana dan Pemikiran Kebudayaan" Jurnal Paradaban Jurnal Rasmi Pusat Dialog Paradaban Jilid 1 University Malaya.

Ismanto, Widodo, 2008, “Identifikasi Potensi Wediombo Sebagai Kawasan Ekowisata Kars di Kabupaten Gunungkidul, Daerah Istimewa Yogyakarta" Jurnal Kepariwisataan Indonesia, Departemen Kebudayaan dan Pariwisata Indonesia, vol. 3 No 1 Maret.

Baiquni, M, 2009, “Belajar dari Pasang Surut Borobudur dan Konsep
Pengembangan Pariwisata Borobudur" Laporan Akhir. Penelitian Fakultas Geografi dan Pusat Studi Pariwisata UGM.

Barika, 2009, “Kajian DampakPengembangan Sektor Pariwisata di Kota Bengkulu; Studi Kasus Kawasan Wisata Pantai Panjang dan Tapak Paderi" Tesis. Sekolah Pascasarjana IPB.

Irawati, Eka Putra \& Roni, 2009, “Kajian Perencanaan Penataan Kawasan Wisata Terpadu Pantai Padang (Studi Kasus Penataan Kawasan Pantai Padang-Padang Bay City)" Penelitian DIPA Universitas Andalas. 